\title{
Invasive Streptococcus pyogenes Infection After Varicella
}

\section{Suçiçeği Seyrinde Gelişen Invaziv Streptococcus pyogenes Enfeksiyonu}

\author{
Ergin Çiftçi', Gizem Güvener ${ }^{2}$, Adem Karbuz ${ }^{3}$ \\ ${ }^{1}$ Department of Pediatrics, Division of Pediatric Infectious Diseases, Ankara University School of Medicine, Ankara, Turkey \\ ${ }^{2}$ Clinic of Pediatrics, Health Sciences University Okmeydani Training and Research Hospital, Istanbul, Turkey \\ ${ }^{3}$ Clinic of Pediatric Infectious Diseases, Health Sciences University Okmeydani Training and Research Hospital, Istanbul, Turkey
}

Cite this article as: Çiftçi E, Güvener G, Karbuz A. Invasive Streptococcus pyogenes infection after varicella. J Pediatr Inf 2019;13(2):e92

A six-years-old male patient was admitted to the hospital with the complaints of painful swelling of the neck and high fever. It was learned that the patient had varicella about two weeks ago and had an increasing swelling over time and high fever for a week. It was a spontaneously drained from the swelling of his neck four days ago, and then the swelling was increased again. The patient was not vaccinated against varicella, because the vaccine was not the national vaccination schedule at that period. On physical examination, crusted varicella lesions were observed in different parts of the body. There was a soft tissue swelling with a diameter of approximately $7 \mathrm{~cm}$ which was painful, red colored, warm and fluctuated on the palpation extending from the supraclavicular region to the upper side of the chest. On ultrasonographic examination of the affected area, the abscess formation was detected. The abscess was drained by thoracic surgery. The abscess culture yielded Streptococcus pyogenes. Intravenous ampicillin-sulbactam and clindamycin treatments were initiated and then redness, tenderness and swelling at the affected area were significantly decreased.

Varicella is highly infectious and generally benign course with a spontaneous recovery disease is common in childhood. It can be prevented by vaccine. The most common complicati- on of varicella is secondary bacterial skin infections. The most common agents in these infections are S. pyogenes and Staphylococcus aureus. In the treatment of invasive S. pyogenes infection, the combination of a penicillin group antibiotic and clindamycin is more effective than the use of a penicillin group antibiotic alone. Clindamycin, which inhibits protein synthesis, also inhibits toxins produced by the agent, provides faster recovery.

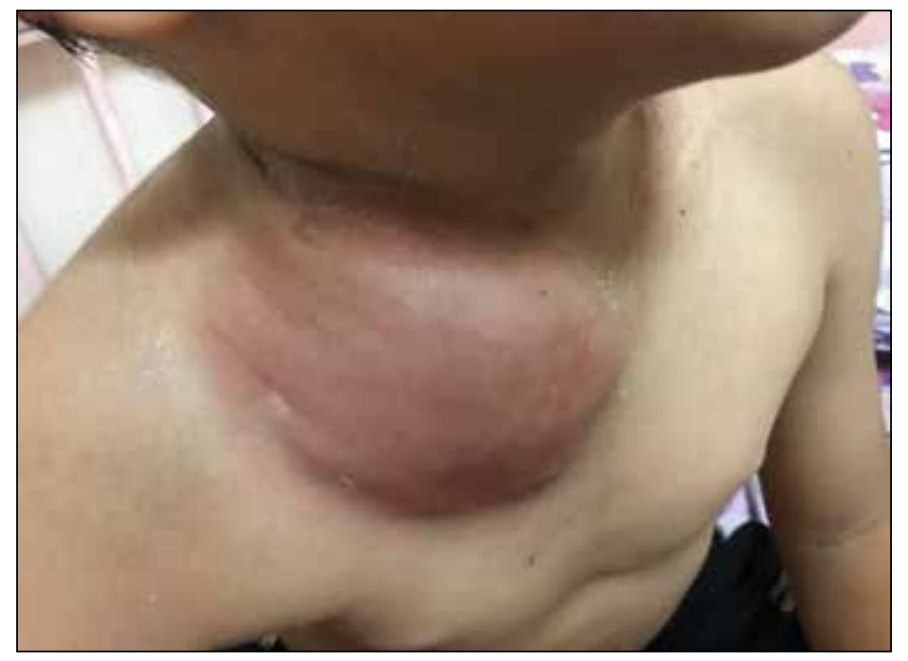

\footnotetext{
Correspondence Address/Yazışma Adresi Ergin Çiftçi

Ankara Üniversitesi Tıp Fakültesi,

Çocuk Sağlığı ve Hastalıkları Anabilim Dalı,

Çocuk Enfeksiyon Hastalıkları Bilim Dalı,

Ankara-Türkiye

E-mail: erginciftci@gmail.com
}

Received: 20.05 .2019 